Korsakov, D.V. (2022). Project management for the implementation of lean manufacturing at an industrial enterprise. International collection of the student works on Jurisprudence. Tuculart Student Scientific, 1 (1), 29-40. Ostrava: Tuculart Edition.

DOI: $10.47451 /$ tss2022-01-03

The paper will be published in Crossref, Internet Archive, ICI Copernicus, Google Scholar, Academic Resource Index ResearchBib, J-Gate, International Scientific Indexing (ISI), eLibrary databases.

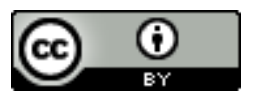

Dmitry V. Korsakov, Bachelor Student, Specialty of Project Management, Department of Project Management, State University of Management, Moscow, Russia.

Scientific adviser: Irina S. Brikoshina, Associate Professor, Deputy Head, Department of Project Management, State University of Management, Moscow, Russia.

\title{
Project management for the implementation of lean manufacturing at an industrial enterprise
}

Abstract: The study subject is the implementation of lean manufacturing using project management technology. The purpose is to substantiate the possibility of using tools and methods of lean production in industrial enterprises. General scientific research methods of external and participant observation, statistical methods, questionnaire survey, elements of process modeling were used. The results showed that the spread of lean production methods in industrial enterprises should be carried out as a project activity, initiating and implementing lean production projects in different structural divisions, on processes of different levels. This requires training in the basics of project management for managers and training in the basics of lean manufacturing for all employees in order to achieve universal inclusion. Shown that even single projects of lean manufacturing bring to the enterprise an increase in efficiency and an increase in labor productivity. The use of certain tools becomes an end in itself, and not a way to solve the identified problems. The participation of people in the implementation of lean manufacturing projects is not always conscious and highly motivated, which hinders the growth of involvement. Insufficient experience in independent implementation of projects in general slows down the implementation of lean manufacturing projects. As a result of the study, the authors show the effectiveness of lean production projects, identify problems specific to industrial enterprises, and identify some areas of activity that contribute to improving operational efficiency.

Keywords: labour productivity, project management, operational efficiency, loss reduction, tools and methods, value, process approach.

Амитрий Викторович Корсаков, студентка 2 курса бакаАавриата, специальность «Управление проектами», кафеАра «Управление проектами», Государственный университет управления, Москва, Россия.

Научный руководитель: Ирина Станиславовна Брикошина, доцент, заместитель завеАующего кафеАрой, кафеАра управление проектом, Государственный университет управления, Москва, Россия.

Управление проектом внеАрения бережливого производства на промышленном преАприятии 
Аннотачия: Предметом исследования является внедрение бережливого производства с использованием технологии проектного управления. Цель - обоснование возможности использования инструментов и методов бережливого производства на промышленных предприятиях. Использованы общенаучные методы исследования: внешнее и включенное наб̆юдение, статистические методы, анкетный опрос, элементы моделирования процессов. Результаты показали, что распространение методов бережливого производства на промышленных предприятиях необходимо осуществлять как проектную деятельность, инициируя и реализуя проекты бережливого производства в разных структурных подразделениях, на процессах разного уровня. А^я этого требуется обучение основам проектного управления менеджеров и обучение основам бережливого производства всех работников с целью добиться всеобщей вкАюченности. Показано, что даже единичные проекты бережливого производства приносят предприятию повышение эффективности и рост производительности труда. Использование тех или иных инструментов становится самоцелью, а не способом решения выявленных проблем. Участие Аюдей в реализации проектов бережливого производства не всегда осознанно и высоко мотивировано, что мешает росту вовлеченности. НеАостаточный опыт самостоятельной реализации проектов в целом тормозит реализацию проектов бережливого производства. В результате проведенного исследования авторами показана результативность проектов бережливого производства, выявлены проблемы, специфичные Аля промышленных предприятий, и обозначены некоторые направления деятельности, способствующие повышению операционной эффективности.

Ключевые слова: производительность труда, проектное управление, операционная эффективность, сокращение потерь, инструменты и методы, ценность, процессный подход.

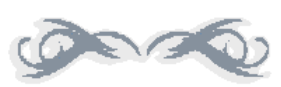

\section{Introduction}

Crisis phenomena in the economy and, as a result, a slowdown in economic growth require managers to find ways to optimize all business processes. Lean production has long established itself as one of the most effective means of improving the operational efficiency of companies in times of crisis. However, it should be noted that lean production methods are not the root cause of the efficient operation of companies, they are only tools that help companies to be even more efficient. So, if Toyota's personnel were not initially disciplined and highly organized, if they were not initially set up for frugality, cost reduction and increasing the welfare of their companies, no lean production methods would show such impressive results (Ono, 2005).

The article considers the possibilities of the enterprise to use the technology of project management in the implementation of lean production. The goal is to substantiate the possibility of using tools and methods of lean production in industrial enterprises. The study identified the difficulties that businesses face when trying to increase, i.e., productivity through lean manufacturing. The possibility of increasing labor productivity was studied on the example of the enterprises of "Kemerovo Gorelektroset" JSC (KGES) and "Kemerovo House-Building Plant" LLC (Kemerovo DSK) using lean production. The object of the research is the implementation of lean production projects at industrial enterprises, the subject is the implementation of lean production using project management technology.

The methodological basis of the research is the applied and fundamental works of foreign and domestic scientists (Ono, 2005; Womack \& Jones, 2014; Davydova, 2012; Sbingo, 2006), specialists in the field of lean production, improvement of business processes and enterprise 
management. Both general scientific (observation, questionnaire survey, measurement, document analysis, statistical analysis) and special (mapping, timing, process modeling elements) methods are used.

\section{Results}

Lean manufacturing is a special way of organizing activities that involves the optimization of all business processes in order to find and eliminate hidden losses and improve production at all its stages. This term is usually understood in two main meanings:

1. A set of practical tools and business technologies to achieve the set goals.

2. A system of provisions closes to philosophical, which characterizes a special attitude to the organization of activities at all levels - from management to a simple worker.

The reason for restructuring activities according to the Lean system can be not only the expressed will of top management. The reasons for implementing lean manufacturing can be the following factors:

- deadlines for fulfilling orders are not met;

- the cost of production is prohibitively high;

- extended delivery times;

- there is a large proportion of defects in the products;

- the share of costs in the financial balance is more than acceptable;

- $\quad$ productivity is limited - there is work in progress.

In general, we can say that the introduction of BP will help to solve the accumulated problems systematically, changing the way the organization works and qualitatively changing the situation for the better.

The main idea is to constantly strive to eliminate any kind of loss. It has the advantage that $80 \%$ of it consists of organizational measures, and only $20 \%$ is investment in technology (Khanafieva, 2007). The first introduction of lean manufacturing into industry occurred in the 1950s. at the Toyota Corporation. The creator of this control scheme was T. Ono, who later made a huge contribution to the development of both theory and practice (Ono, 2005). No less contribution was made by his colleague S. Shingo, who, among other things, created a method for quick changeover (Shingo, 2006). Later, American specialists investigated this system, improved it and called it lean manufacturing (Liker, 2011).

D.P. Womack and D.T. Jones define lean manufacturing as a breakthrough approach to management and quality management that ensures long-term competitiveness without significant capital investments (Womack \& Jones, 2014). It helps to identify value, to best sequence the actions that create it, to do the work without unnecessary interruptions, and to do it more and more efficiently (Tsarenko \& Guselnikova, 2019). D.P. Hobbs singles out the design and implementation of a production line as the main task of lean manufacturing, which allows manufacturing different types of products in a set time (Hobbs, 2007). M. Vader believes that an important part of the concept of lean production is continuous improvement and participation in this process of the entire team of the enterprise (V ader, 2005).

For the successful implementation of the lean project, it is necessary to clearly understand how we want to see the end result and how to achieve it, to master all the work tools and 
implementation methods. The introduction of lean manufacturing in industrial enterprises involves intensifying efforts to use more and more new tools, which is associated with the need to increase the level of competitiveness. In this regard, a clear model for the implementation of lean manufacturing tools in enterprises is needed.

According to the concept of lean manufacturing, all activities of the company can be divided into processes and operations that add value to the consumer, and those that do not bring any value. It is possible to single out direct losses, i.e., works that in themselves do not add value and do not contribute to its addition. Value is created during the performance of production or service processes. Adding value to the end product for the customer is the main objective of lean manufacturing. The essence of lean manufacturing is reflected in its principles (Levinson \& Rerik, 2007; Luyster \& Tepping, 2008; Davydova et al., 2019):

- Determine the value of a particular product. To get a valuable product at the output, the manufacturer must see through the eyes of the consumer what parameters the product must have in order to become a value.

- Define the value stream for this product, i.e., describe the value-creating and non-valuecreating activities that go through all the processes from concept development to production launch.

- Ensure the continuous flow of the product value stream.

- Allow the consumer to "pull" the product to meet the customer's requirements.

- Continuously strive for excellence, focusing on the consumer (client).

The application of lean manufacturing technology involves a certain way of thinking, in which any activity is considered in terms of value for the consumer and the reduction of all types of waste. An analysis of the literature has shown that with the help of lean production, they achieve cost reduction, terms for the development of new products, terms for creating products, production and storage areas, and ensuring the guarantee of delivery of products to the customer (Sadykova, 2018; Strushchenko \&o Duganova, 2018; Ivanova, 2010; Galyamina, 2013). In Russia, interest in the use of lean production has increased after the approval of the passport of the national project "Labor Productivity and Employment Support" (Laborproductivity and employment support, 2018), which set the task of using lean production tools to increase competitiveness and optimize business processes in order to increase labor productivity, conduct large-scale training, and even develop a federal state educational standard for higher education in the Lean production direction.

In Russian practice, there are many examples of successful implementation of lean production projects in various sectors of economic activity. Large corporations manage to achieve the greatest success (Emanakov et al., 2015; Golubenko \& Svekolnikova, 2019; Lyskova, 2019). However, with a skillful combination of managerial competence and professionalism of employees, successful practices are also possible in smaller enterprises.

At the same time, in order to disseminate best practices and generalize the experience gained, it is necessary to scientifically understand the possibilities of applying lean production tools, and identifying the specifics for different business entities, and motivating staff, and building training. With this approach, the development of lean manufacturing in the Russian Federation can have a multiplicative effect. The results of the successful implementation of lean 
manufacturing are an increase in labor productivity, a reduction in the used area, stocks, duration of processes, rejects, etc. (Indeikina, 2015; Sychanina et al., 2019; Skorobogatova, 2019; Chuprik \& Baida, 2020).

Barriers to achieving the desired results are the following factors (Naumenko, 2017):

- staff training and financing of this process is not always realized by management;

- the staff itself is not always willing to learn and apply the elements of lean production;

- the introduction of lean manufacturing turns into a campaign and becomes an end in itself;

- there are not enough specialists in organizations capable of managing change;

- managers strive to get results quickly, without building a long-term strategy, without investing resources in staff training;

- lack of specialists in the field of lean manufacturing;

- inconsistency in the formation of the production system.

There are many algorithms for implementing the lean concept. Researchers in the field of lean manufacturing (T. Ono, D. P. Womack, M. Vader, D. K. Liker, S. Singo, D. P. Hobbs) proposed their step-by-step algorithms for implementing lean manufacturing in an enterprise. To date, the most popular is the algorithm of the American researcher D.P. Wumek, who made a serious contribution to the promotion of the lean concept. This man is the bestselling author of The Machine That Changed the World. He proposed the most relevant step-by-step algorithm for implementing lean manufacturing in an enterprise:

Select a leader in the enterprise who is respected among the workers and has a history of implementing successful projects. In other words, a person who will be trusted. This person needs to take responsibility and direct the implementation process.

The entire implementation team should receive basic training in the basics of lean manufacturing and key tools.

Identify or create a crisis. A crisis in an enterprise can serve as a good impetus for the implementation lean. But there are problems in any enterprise, it is not necessary to wait for the company's crisis.

It is better to start implementing lean manufacturing in stages. It is not necessary to globally revise the entire production process. At the initial stage, you can push employees to eliminate losses wherever they notice them. After a successful experience, you can move on to more complex tasks, concentrating on the specific goals of the enterprise (order time, production cost, quality).

Value stream mapping. Try to represent the production process in the form of a flow map, breaking it into separate processes. This will help to detect bottlenecks, problems and losses. It is also necessary to think over a plan for their elimination and present a map of the future flow.

Having made a flow map and understanding the weak points, it is necessary to move on to practice. Information about the progress of the implementation process and its results should not be hidden from employees.

Striving for fast results. Lean manufacturing is a long-term strategy, but in the early stages it is better to focus on immediate results. Therefore, it is recommended to start with simpler tasks. 
Launching the kaizen system. The more employees are involved in the common cause of continuous improvement, the faster positive results can be achieved.

We selected two companies for analysis. In one of them (KGES), there are only intentions of the initiative group to use lean production tools to increase labor productivity. In another (Kemerovo DSK), a number of projects have already been implemented, including under the leadership of representatives of ANO

"Federal Center of Competence in the Field of Labor Productivity" (FCC), established on December 18, 2017 by decision of the Presidium of the Council under the President of the Russian Federation for Strategic Development and Priority Projects. Currently, the FCC is the operator of the national project "Labor Productivity and Employment Support" in terms of targeted support for enterprises.

KGES is one of the largest utilities in the region. 560 specialists provide reliable uninterrupted power supply to residents, social organizations and industry of the regional capital of Kuzbass. At the beginning of 2020, the company's management announced the need to initiate and further implement projects to optimize business processes using lean production tools.

An analysis of organizational documents and experience in applying lean manufacturing tools showed that the most promising areas for implementing the lean concept for electric grid companies are:

- development of solutions to compensate for power losses;

- elimination of unproductive costs;

- optimization of the repair process;

- document flow optimization;

- reduction of receivables;

- reduction of costs in the structure of the cost of transmission and transportation of electricity;

- rational organization of the workplace and space in order to increase productivity, quality and safety.

One of the objectives of the study was to initiate and implementation of pilot projects of lean manufacturing. During the VSM-analysis of the process of coordinating daily work with the management of the operational dispatch service of the KHPP, losses in waiting, overproduction, and unnecessary movements were identified. Below are the problems that were identified only when one of the many processes was running:

- late driver;

- delay in the issuance of the equipment necessary for work (lack of stock, absence) to employees;

- loss of time to search for and receive material in the warehouse by employees;

- untimely coordination of the composition of participants, the perimeter of work by the heads and heads of structural divisions;

- lack of specialists for the available number of machines;

- idle time of drivers and working personnel at the time of coordination by technicians of 
work for the day and at the time of issuance of equipment to them;

- lack of up-to-date information on subscription payments;

- lack of consumables at the place of work due to incorrect information.

All identified problems can be fully resolved at the enterprise level; their solution requires mainly organizational measures. When they were solved, it became possible to reduce the time of the process by 2 times, to get rid of electricity losses in electrical networks. When analyzing the work of the company's fleet using tools and methods of lean production (timing, Pareto diagram, "5 whys"), the reasons for downtime were identified and the groups of vehicles used as inefficiently as possible were identified.

$80 \%$ of transport downtime due to lack of demand is brought by the first 5 types of vehicles: emergency (road service facilities), aerial platforms and cranes, tractors and excavators, buses, cars. All other vehicles account for only $20 \%$ of losses. The equipment utilization rate turned out to be $57 \%$ (calculations were made on the basis of data from the transport department, which takes into account the downtime for each working day for each type of transport) (Fig. 1).

Thus, the pilot projects for the enterprise have shown that lean production tools can significantly increase the economic efficiency of the enterprise. There were also definitions of modes of transport that are idle due to low air temperature or lack of a driver.

The overall economic effect of the proposed measures in the form of reducing staff expectations, reducing the cost of fuel and lubricants, reducing vehicle downtime, reducing electrical losses in networks and overproduction will, including due to the installation of new metering devices, exceed 7 million rubles. in year. Based on the experience studied, the results of pilot projects and the financial and economic state of KPSP, in the course of the study, an algorithm for introducing lean production at the enterprise was proposed.

Algorithm for implementing lean manufacturing tools:

- Establishment of a lean-technologies department for the implementation of a lean production system at the KGES enterprise;

- Development of a schedule for the implementation of lean production in the divisions of the enterprise;

- Training of personnel of all levels in the principles of lean production;

- Selection and analysis of the pilot site;

- Development of a pilot project in accordance with the schedule;

- Implementation of a pilot project;

- Evaluation of the efficiency of the KGES enterprise after the implementation of a pilot project on the introduction of lean production.

The introduction of tools and methods of lean manufacturing in an organization should be viewed as a project that is directly led by the head or his deputy. This project should be limited in terms, which distinguishes the project activity from the operational one. The formation of project teams, the definition of the scope of work on the project (hierarchical structure), the identification of risks, the establishment of quality parameters for the work performed are of great importance. Particular attention should be paid to working with stakeholders: lean projects can and should be carried out by specialists with basic knowledge and project management skills. The second enterprise in the study is Kemerovo DSK, whose main activities are the manufacture 
and supply of precast concrete, concrete, mortar, reinforcing welded and embedded parts. As part of a federal project

"Targeted support for increasing labor productivity at enterprises" the company was among the enterprises of Kuzbass, which, with the support of Rosatom State Corporation, FCC specialists, since 2018 have been successfully implementing the principles, methods and tools of lean production at their sites, allowing to reduce the loss of working time, optimize production flow, thereby increasing labor productivity by up to $40 \%$. The FCC, together with the working group of the enterprise, identifies bottlenecks, improves processes by eliminating losses and identifying reserves. According to the director of the plant, participation in the program is an important stage in the development of each member of the working group and for the plant as a whole. The management of the enterprise was trained under the program "Fundamentals of Lean Manufacturing" using standardized methods,

The first implemented project at the Kemerovo DSK within the framework of lean manufacturing was "Improving Labor Productivity in Pallet Production", which started in June 2018. The reasons for choosing the project were the lag between the production speed and the installation speed during construction at several sites (in Kemerovo and Novokuznetsk) and an increase in the cost of one $\mathrm{m}^{3}$ of manufactured products. The goal of the project is to increase the pallet turnover rate from 0.8 pallets/day to 1.2 pallets/day. The planned effect is an increase in the volume of products manufactured at pallet production from $100 \mathrm{~m}^{3} /$ day to $150 \mathrm{~m}^{3} /$ day, a decrease in corrosion of the metal of the bead equipment. After timing and building a current value stream map, the project participants identified a number of problem areas and reorganized the process, improving it and reducing unproductive losses:

We changed the scheme of moving the reinforcement cage around the shop, reducing the distance of moving the reinforcement cage by $60 \mathrm{~m}$, the number of operations from 8 to 5 , and the time for moving the reinforcement cage from 18 minutes. up to $8.3 \mathrm{~min}$.

Changed the location of the warehouse for thermally hardened rebar, reducing the distance of rebar movement from $30 \mathrm{~m}$ to $6 \mathrm{~m}$, the number of operations from 3 to 1 , and the time to move rebar from 5 minutes. up to 3 min.

Instead of paper drawings, their electronic counterparts began to be used.

The formwork warehouse was moved, which reduced the time of formwork installation from 43 minutes to 43 minutes. up to 26 min.

The implementation of this lean manufacturing project laid the foundation for the implementation of other projects that improve operational efficiency.

As a result of mapping the loading process of finished products, unproductive downtime per day (626 minutes) was identified. From the analysis of the value stream map, it became clear that the most problematic process is the queue for loading, which occurs due to the lack of a logistics scheme, violation of temporary standards for loading one car, and the non-working state of the device for chipping. The overall flow efficiency was $70 \%$. After analyzing the data obtained, we can conclude that fine-tuning the process will help to evenly divide the work between specialists at different stages by identifying bottlenecks and increase the consistency of actions. The enterprise has a real opportunity to improve the efficiency of the production process and reduce the identified losses in the finished product shop, if you develop a logistics scheme for the shipment of material, create an application - a program for scheduling the shipment of 
goods, develop a standard operating card for a logistician. This can reduce overhead, reduce the number of processes that do not create value, ensure the rhythm of operations, reduce waiting times. Using the principles and tools of lean manufacturing, Kemerovo DSK has achieved improvements in terms of reducing the occupied space, putting things in order at the workplace, reducing the time to complete operations, and increasing operational efficiency. ensure the rhythm of operations, reduce waiting times. Using the principles and tools of lean manufacturing, Kemerovo DSK has achieved improvements in terms of reducing the occupied space, putting things in order at the workplace, reducing the time to complete operations, and increasing operational efficiency. ensure the rhythm of operations, reduce waiting times. Using the principles and tools of lean manufacturing, Kemerovo DSK has achieved improvements in terms of reducing the occupied space, putting things in order at the workplace, reducing the time to complete operations, and increasing operational efficiency.

As noted above, at the initial stage, review training of several specialists took place at the enterprise with the inclusion of the enterprise in federal projects. Further training of the management staff was carried out at a fairly high level. However, participation itself in training and searching for bottlenecks, developing measures to improve them is not considered by the participants as participation in the project, many perceive it as an extra burden, as an additional assignment (most often unpaid), performers do not feel like members of one project team. All of the above gives rise to risks and problems that need and can be managed. To a large extent, they coincide in most enterprises that have decided to apply the concept of lean production (Tikhonina, 2018; Belysh, 2018).

Activities to improve operational efficiency should be carried out in a project mode. A project is a time-limited intention to create a unique product or service, which is a consistent and interconnected set of activities and processes aimed at achieving the main goal, in the form of a large-scale task (Vershinin, 2020). Project activities are not formally fixed at this enterprise. However, many experts are thinking about combining the concept of lean manufacturing and project management.

In the course of a questionnaire survey conducted in July 2020 of managers and specialists of the enterprise, it was revealed that more than $90 \%$ of those surveyed believe that the project approach would be useful to the organization, and $20 \%$ spoke in favor of the full-scale implementation of the project approach on an ongoing basis. It is known that any new process or change in work is perceived by the staff as a danger of losing their place or not meeting new requirements. Therefore, employees are always against any changes, and there is a risk that employees will refuse to comply. For two years of using lean manufacturing tools, the company has accumulated its own experience. FCC specialists made a significant contribution to the development of lean production. Thus, professional advice from specialists and managers has played a decisive role.

According to the results of the study, it is possible to identify a number of areas necessary for the implementation, reducing the likelihood of adverse events in the implementation of the concept of lean production. This is the creation of a project office and a standard operating procedure that provides for the procedure for initiating, planning and implementing projects; improvement of personnel training methods; introduction of acquired knowledge into production processes. 


\section{Conclusion}

The study confirmed the hypothesis that the tools and methods of lean manufacturing can be used in any industrial enterprise. Successful implementation of lean production projects contributes to the growth of labor productivity, employee income, reduction of unnecessary stocks, occupied areas, more rational use of natural resources. However, to achieve significant results across the entire enterprise, the obligatory conditions must be met:

- interest of the leader of the organization;

- availability of competencies in the field of project management;

- creation of a system of multi-level training in lean production for employees of the enterprise;

- transformation of the employee motivation system with a focus on continuous improvement of performance;

- creation and development of programs for the formation of a thrifty worker;

- using the capabilities of digital technologies to solve the identified problems;

- orientation of project activities for the initiation, planning, implementation and completion of lean production projects to improve the skills of employees, ensuring decent and safe work;

- the formation of standard operating cards, procedures and their strict observance should become part of the corporate culture of employees.

Ensuring the above conditions can be the key to the successful implementation of tools and methods of lean production in order to increase the operational efficiency of enterprises; they are common to enterprises in any field. However, industrial enterprises have their own specifics. The problem of low labor productivity here is one of the most acute, which means that the use of lean technologies is more relevant. A significant number of enterprises in the Kemerovo region are vertically integrated, which predetermines the specifics of the initiation, planning and implementation of lean production projects. The quality of the labor force employed in industry is low, which makes it difficult to organize training and create a culture of lean manufacturing.

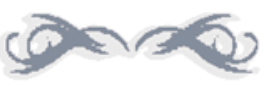

\section{References:}

Belysh, K.V. (2018). An integrated approach to the implementation and evaluation of the effectiveness of the implementation of lean production at an industrial enterprise. Vestnik UrFU. Economics and Management Series. 4(5), 751-771. (in Russian)

Chuprik, M.A., \& Baida, E.A. (2020). The concept of lean production as a tool for increasing labor productivity. Construction Equipment and Technologies, 1, 47-52. (in Russian)

Davydova, N.S. (2012). Lean production. Izhevsk: Publishing House of the Institute of Economics and Management of UdGU. (in Russian)

Davydova, N.S., Titov, I.G., Sycheva, E.V., \& Pozmogova, N.P. (2019). Improving the system of motivation of the personnel of a medical organization in the implementation of the principles of lean production. Ural State Medical University, 1(5), 133-135. (in Russian) 
Emanakov, I.V., Grodzensky, S.Ya., Ovchinnikov, S.A. (2015). First steps towards "lean production". Bulletin of MSTU MIREA, 1, 278-285. (in Russian)

Galyamina, I.G. (2013). Management of processes. 2nd ed. St. Petersburg: Piter. (in Russian)

Golubenko, O.A., \& Svekolnikova, O.Yu. (2019). Comparative analysis of the implementation of "Lean production" at Russian and foreign enterprises. Modern problems of commodity science, economics and food industry: Sat. scientific tr. conf., 31-34 (February 25, 2019). Saratov. (in Russian)

Hobbs, D.P. (2007). Implementing Lean: A Practical Guide to Business Optimization. Minsk: Grevtsov Publisher. (in Russian)

Indeikina, A.A. (2015). Russian experience in implementing the concept of "lean production". Master's journal, 1, 337-341. (in Russian)

Ivanova, I.A. (2010). Management. 3rd ed. Moscow: Rior. (in Russian)

Khanafieva, S. (2007, February 19). How popular is lean production in Russia. Expert Ural. No. 7. Retrieved July 13, 2020 from https://expert.ru/ural/2007/07/vihanskiy/ (in Russian)

Labour productivity and employment support (2018, December 24). Passport of the national project (program). No. 16. (Approved by the Presidium of the Council under the President of the Russian Federation for Strategic Development and National Projects). Garant. Retrieved July 15, 2020 from http://base.garant.ru/72185994/ (in Russian)

Levinson, U.A., \& Rerik, R.A. (2007). Lean production: a synergistic approach to reducing losses. Moscow: Standards and quality. (in Russian)

Liker, D.K. (2011). Tao of Toyota: 14 principles of management of the world's leading company. 6th ed. Moscow: Alpina Publisher.

Luyster, T., \& Tepping, D. (2008). Lean production: from words to deeds. Moscow: Standards and quality. (in Russian)

Lyskova, I.E. (2019). Implementation of sustainable development and lean production models in the system of environmental and social security of a modern organization (on the example of the Rosatom State Corporation). Global Nuclear Safety, 4, 85-95. (in Russian)

Ono, T. (2005). The Toyota Production System. Moving away from mass production. Moscow: Institute of Complex Strategic Studies. (in Russian)

Naugolnova, I.A. (2014). Domestic and foreign experience of using the system of lean production at industrial enterprises. The Proceedings of A.I. Herzen Russian State Pedagogical University, 170, 95-99. (in Russian)

Naumenko, E.Yu. (2017). Problems of implementation of lean production in Russia and recommendations for their elimination. Innovation Science, 1(4), 143-146. (in Russian)

Sadykova, E.A. (2018). The results of the implementation of lean production methods in the oil and gas industry in Russia. Economics and Society, 1, 1247-1250. (in Russian)

Shingo, S. (2006). Study of the Toyota production system from the point of view of production organization. Moscow: Institute of Complex Strategic Studies. (in Russian)

Skorobogatova, O.M. (2019). Lean production and TWI: facets of high labor productivity. Quality Management, 4, 250-262. (in Russian)

Strushchenko, A.L., \& Duganova, E.V. (2018). Implementation of lean production at a motor transport enterprise. International Student Scientific Bulletin, 3-8, 1294-1296. (in Russian) 
Sychanina, S.N., Mironchuk, V.A., Sholin, \& Yu.A. (2019). Implementation of lean manufacturing technologies as a way to increase labor productivity at public transport enterprises. Bulletin of the Academy of Knowledge, 3, 238-244. (in Russian)

Tikhonina, A.S. (2018). Problems in the implementation of lean production tools. Innovatika2018: Collective Materials of the 14th International Conference Schools for Students, Graduate Students and Young Scientists, 274-276 (April 26-27, 2018). Tomsk. (in Russian)

Tsarenko, A.S., \& Guselnikova, O.Yu. (2019). Projects "Lean Region”, “Lean Clinic”, "Lean City" as steps towards the creation of "Lean Government": evaluation of implementation Lean initiatives in the public sector of the Russian Federation. Public administration. Electronic Bulletin, 73, 167-203. (in Russian)

Vader, M. (2005). Lean production tools. Moscow: Alpina Business Books; Center OrgProm; Perm: IPK Zvezda. (in Russian)

Vershinin, V.P. (2020). Verification of differences between the project and the program. Vestnik URAO, 1, 108-116. (in Russian)

Womack, D.P., \& Jones D.T. (2014). Lean production: how to get rid of losses and achieve prosperity for your company. 8th ed. Moscow: Alpina Publisher. (in Russian)

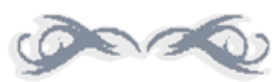

\section{Appendix}

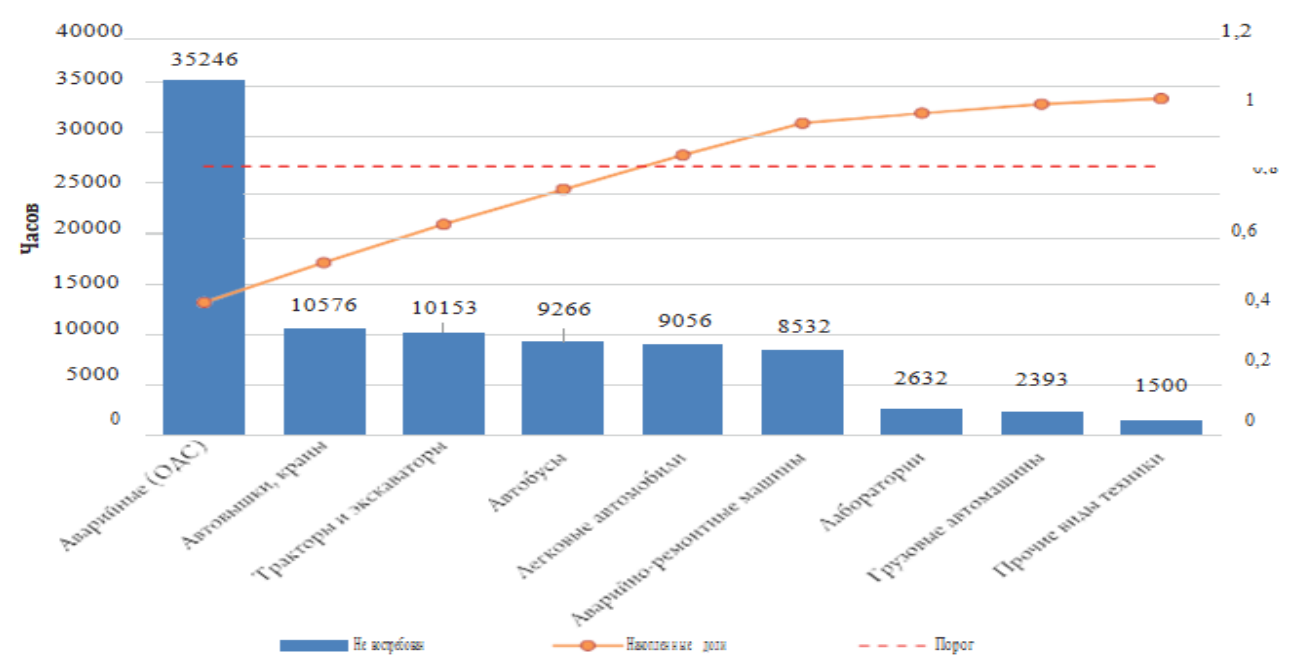

Figure 1. Pareto chart for unclaimed transport 